\title{
KONTRIBUSI ORANG TUA DI SEKOLAH DASAR NEGERI 325 POLEWALIE KECAMATAN GILIRENG KABUPATEN WAJO
}

\author{
Ashari \\ Moh. Natsir Mahmud \\ Safei \\ SDN 325 Poliwalie Kecamatan Gilireng Kab. Wajo \\ Ashariputragilireng@yahoo.com
}

\begin{abstract}
Abstrak: Tulisan ini akan menyoroti tentang kontribusi orang tua di Sekolah Dasar Negeri 325 Polewalie Kecamatan Gilireng Kabupaten Wajo dalam meningkatkan prestasi belajar peserta didik. Penelitian ini bersifat deskriptif dengan lokasi penelitian pada Sekolah Dasar Negeri 325 Polewalie Kecamatan Gilireng Kabupaten Wajo. Pendekatan yang digunakan adalah pendekatan pedagogis dan psikologis. Data diperoleh melalui metode wawancara dan dokumentasi dengan instrumen penelitian adalah pedoman wawancara dan alat dokumentasi seperti kamera dan flasdish. Aktifitas dalam analisis meliputi reduksi data (data reduction), penunjukan data (display daya) serta penarikan kesimpulan dan verifikasi (conclusion drawing/ verificatiori). Data diuji keabsahannya dengan cara melakukan perpanjangan pengamatan, peningkatan ketekunan, dan triangulasi yang mencakup triangulasi sumber dan triangulasi teknik.
\end{abstract}

Hasil penelitian menunjukkan bahwa kontribusi antara orang tua dan pendidik dalam meningkatkan prestasi belajar dapat meningkatkan belajar anak di sekolah, sangat ditentukan oleh kerja sama orang tua dan pendidik karena pedidikan merupakan usaha untuk mendewasakan orang yang belum dewasa sehingga mampu berdiri sendiri sebagai manusia dewasa yang penuh ilmu pengetahuan.

Sebagai implikasi dari penelitian ini, orang tua lebih memperhatikan potensi dan kreativitas yang dimiliki anak dan memberikan dukungan dan motivasi kepada anak dengan menciptakan suasana pembelajaran dirumah yang dapat mengasah potensi dan kreativitas pada anak.

\section{Keywords: Kontribusi Orang Tua, Peran Orang Tua, Fungsi Keluarga}

\section{PENDAHULUAN}

Pada dasarnya setiap anak membutuhkan pendidikan, karena dengan pendidikan anak dapat mengembangkan minat dan bakat yang dimilikinya. Salah satu upaya untuk mengembangkan bakat dan minat tersebut adalah melalui suatu lembaga formal atau non formal. Di lembaga tersebut kegiatan belajar merupakan kegiatan yang paling pokok. Tidak disangkal lagi jika dalam belajar meraih prestasi, seseorang dipengaruhi oleh beberapa faktor. Sehingga hal ini penting bagi para pendidik didalam mengatur dan mengendalikan faktor-faktor yang mempengaruhi belajar yang sedemikian rupa hingga dapat terjadi proses belajar yang optimal.

Proses belajar peserta didik dipengaruhi oleh beberapa faktor, secara umum faktor tersebut dapat digolongkan menjadi dua, yaitu faktor intern dan faktor ekstern. Faktor intern yaitu faktor yang terdapat dari dalam peserta didik, yakni keadaan atau 
kondisi jasmani dan rohani peserta didik. Sedangkan faktor ekstern yaitu faktor yang terdapat dari luar peserta didik, yakni kondisi lingkungan sekitar peserta didik, seperti orang tua, pendidik, teman dan lain-lain. Jadi, karena faktor-faktor tersebut di ataslah, muncul peserta didik-peserta didik yang berprestasi tinggi dan berprestasi rendah atau gagal sama sekali. ${ }^{1}$ Faktor-faktor tersebut dapat mempengaruhi baik buruknya prestasi peserta didik.

Salah satu faktor yang mempengaruhi keberhasilan belajar anak atau prestasi peserta didik adalah yang berkaitan dengan orang tua yakni keterlibatan orang tua dalam pendidikan anaknya. Orang tua memegang tugas penting terhadap perkembangan fisik dan mental anaknya. Tugas orang tua yang paling penting terletak pada tugas edukasi (mendidik). Tugas ini terlihat dari pola asuh yang diterapkan oleh orang tua kepada anaknya.

Keluarga merupakan masyarakat pertama atau merupakan kelompok sosial pertama bagi orang untuk berinteraksi terhadap perkembangan kepribadian seseorang, pangaruh ketuarga sangatlah besar. Pendidikan dalam keluarga merupakan pendidikan pertama dan utama yang dilakukan orangtua. Dalam keluarga orangtua mendidik anakanaknya dalam upaya sosialisasi bagi anak anak, menanamkan sopan santun, tata krama, norma atau nilai dalam masyarakat. Keluarga merupakan lingkungan pertama yang tugasnya meletakkan dasar perkembamgan anak. ${ }^{2}$ OIeh karena itu dapat dipahami betapa pentingnya bimbingan orangtua terhadap perkembangan anak-anaknya.

Di dalam keluarga anak belajar bagaimana ía harus berperilaku, berkenalan dengan nilai-nilai dan norma-norma perilaku. Pendidikan dalam keluarga turut pula mempengaruhi perkembangan diri seseorang. Dalam keluarga anak memperoleh stimulasi sehingga anak memperoleh kemampuan, baik kemampuan mengenali maupun kemampuan dalam menganalisis. Keluarga sebagai unit terkecií dalam kehidupan bermasyarakat memberikan kontribusi yang penting terhadap masyarakat.

Banyak orang tua bekerja sama dengan lembaga bimbingan belajar untuk memberikan tambahan pelajaran atau les, ada juga yang mengundang narasumber datang ke rumah untuk memberikan les di rumah. Para pendidik dan orang tua untuk meningkatkan prestasi para peserta didik sangat terfokus pada perbaikan diri peserta didik.

Keterlibatan orang tua memegang peranan yang sangat penting dalam perkembangan umum anak, khususnya dalam belajar anak. Efek dari keterlibatan orang tua dalam belajar anak salah satunya anak menjadi sukses dalam pembelajaran di sekolah, karena orang tua mendukung dan terlibat dalam pendidikan anak. Kegiatan belajar anak di sekolah cukup terbatas, sedangkan siswa waktunya terbanyak merupakan tanggung jawab orang tua di rumah. Keterlibatan orang tua di rumah berupa bimbingan belajar dan dukungan lain agar anak dapat mencapai prestasinya di sekolah. Keterlibatan orang tua dalam belajar anak sangat dibutuhkan, khususnya pada anak usia sekolah. Di dalam sekolah anak memperoleh pelajaran dari guru.

Hasil penelitian mnyatakan bahwa terdapat pengaruh yang signifikan antara keterlibatan orang tua dalam belajar terhadap prestasi belajar siswa kelas V Sekolah dasar Negeri se-Daerah Binaan III Kecamatan Petarukan Kabupaten Pemalang. Hal ini dapat dibuktikan dengan nilai analisis regresi linier sederhana pada output ANOVA

\footnotetext{
${ }^{1}$ Muhhibbin Syah, Psikologi Pendidikan dengan Pendekatan Baru (Bandung: Remaja Rosdakarya, 2011), h. 129.

${ }^{2}$ Sri Harini, Mendidik Anak Sejak Dini (Yogyakarta: Kreasi Wacana, 2003), h. 42.
} 
kolom sig. sebesar 0,000. Hal ini berarti Ho ditolak karena nilai signifikansi lebih kecil dari $0,05(0,000-0,05)$. Besarnya pengaruh keterlibatan orang tua dalam belajar terhadap prestasi belajar siswa tergolong kuat dengan koefisien $\mathrm{R}$ sebesar 0,616 . Kontribusi variabel $\mathrm{X}$ terhadap $\mathrm{Y}$ sebesar 0,379 atau 37,9\% kemudian sisanya $62,1 \%$ ditentukan oleh faktor lain. Sementara besar kecilnya prestasi belajar dalam pembelajaran dapat diprediksi melalui persamaan regresi $\hat{Y}=34,760+0,489 X$.

Tulisan ini akan menyoroti tentang kontribusi orang tua di Sekolah Dasar Negeri 325 Polewalie Kecamatan Gilireng Kabupaten Wajo dalam meningkatkan prestasi belajar peserta didik.

\section{KAJIAN TEORETIS}

Orang tua adalah orang yang bertanggung jawab dalam satu keluarga atau rumah tangga yang biasa disebut ibu/bapak. Berdasarkan uraian diatas dapat disimpulkan bahwa peran orang tua merupakan suatu pengharapan manusia terhadap cara individu tentang bagaimana ia harus bersikap sebagai orang yang mempunyai tanggung jawab dalam satu keluarga.

a. Peranan Orang Tua Dalam Keluarga

Orang tua merupakan orang yang lebih tua atau orang yang dituakan, namun umumnya di masyarakat pengertian orang tua itu adalah orang yang telah melahirkan kita yaitu ibu dan bapak, selain yang telah melahirkan kita ke dunia ini ibu dan bapak juga yang mengasuh dan yang telah membimbing anaknya dengan cara memberikan contoh yang baik dalam menjalani kehidupan sehari-hari, selain itu orang tua juga memperkenalkan anaknya ke dalam hal-hal yang terdapat di dunia ini dan menjawab secara jelas tentang sesuatu yang tidak dimengerti oleh anak, maka pengetahuan pertama diterima oleh anak adalah dari orang tuanya karena orang tua adalah pusat kehidupan rohani sianak dan sebagai penyebab berkenalnya dengan alam luar, maka setiap reaksi emosi anak dan pemikirannya di kemudian hari terpengaruh oleh sikapnya terhadap orang tua.

Kata orang tua merupakan kalimat majemuk, yang secara leksikal berarti "Ayah ibu kandung: orang yang dianggap tua (cerdik, pandai, ahli dan sebagainya), orangorang yang dihomati (disegani). ${ }^{3}$

Berdasarkan pengertian etimologi, pengertian orang tua yang dimaksud pada pembahasan ini ialah seseorang yang telah melahirkan dan mempunyai tanggung jawab terhadap anak-anak baik anak sendiri maupun anak yang diperoleh melalui jalan adopsi, ${ }^{4}$ orang tua akibat adopsi dimaksudkan yaitu dalam kategori "Orang tua" yang sebenarnya karena dalam praktek kehidupan sehari-hari, orang tua karena adopsi mempunyai tanggung jawab yang sama dengan orang tua yang sebenarnya, dalam berbagai hal yang menyangkut seluruh indikator kehidupan baik lahiriyah maupun batiniyah, orang tua dalam hal ini yaitu suami istri, adalah figur utama dalam keluarga, tidak ada orang yang lebih utama bagi anaknya selain dari pada orang tuanya sendiri, apalagi bagi adat ketimuran, orang tua merupakan simbul utama kehormatan, maka orang tua bagi para anak merupakan tumpuan segalanya.

Istilah orang tua atau keluarga dalam sosialisasi menjadi salah satu bagian ikon yang mendapat perhatian khusus, keluarga dianggap penting sebagai bagian bagi

\footnotetext{
${ }^{3}$ Anton Moeliono, Kamus besar bahasa Indonesia (Jakarta : Balai Pustaka, 1989), h. 629.

${ }^{4}$ Jalaludin Rahmad, Islami Alternatif Ceramah-Ceramah Dikampus (Bandung: Mizan, 1993) h. 121 .
} 
masyarakat secara umum. Individu terbentuk karena adanya orang tua dan dari keluarga pada akhirnya akan membentuk masyarakat, sedemikian penting peran orang tua atau posisi keluarga dalam pembentukan masyarakat. Dari definisi tersebut secara umum dapat diambil pengertian bahwa orang tua atau keluarga adalah:

1. Merupakan kelompok kecil yang umumnya terdiri atas ayah, ibu dan anak-anak.

2. Hubungan antar anggota keluarga dijiwai oleh suasana afeksi dan rasa tanggung jawab.

3. Hubungan sosial di antara anggota keluarga relatif tetap dan didasarkan atas ikatan darah, perkawinan atau adopsi.

4. Orang tua berkewajiban memelihara, merawat, dan melindungi anak dalam rangka sosialisasinya agar meraka mampu mengendalikan diri dan berjiwa sosial. ${ }^{5}$

Untuk mencapai interaksi yang baik antara orang tua dengan anak-anaknya maka dalam keluarga itu harus menjalankan peranannya sesuai dengan fungsi dan kedudukannya, baik di dalam keluarga itu sendiri maupun di lingkungan masyarakat berikut ini penulis akan menguraikan peranan-peranan tersebut:

1) Peranan Ibu

Peranan seorang ibu bagi anak-anaknya sangat besar artinya, karena anak-anak lebih dekat hubungannya kepada ibu daripada kepada ayahnya dalam kehidupan seharihari, oleh karena itu seorang ibu harus benar-benar berfungsi dalam menunaikan tugasnya, antara lain meliputi pemeliharaan pendidikan anak-anaknya agar mereka menjadi anak yang berguna dan menjadi anak yang shaleh.

Pembinaan pendidikan seorang ibu terhadap anaknya merupakan pendidikan dasar yang tidak dapat diabaikan sama sekali. Maka dari itu, seorang ibu hendaknya bijaksana dan pandai mendidik anak-anaknya. Nyatalah betapa berat tugas seorang ibu sebagai pendidik dan pengatur rumah tangga. Baik buruknya pendidikan seorang ibu terhadap anaknya akan berpengaruh besar terhadap perkembangan dan watak anaknya dikemudian hari, karena ibu adalah seseorang yang pertama berkomunikasi langsung dengan anaknya. Pernyataan rasa kasih sayang dan perlindunngan merupakan hal sangat penting bagi anak untuk mengembangkan rasa percaya diri dan terhindar dari rasa takut. Gelisah yang akan mengganggu perkembangan jiwa anak.

Peranan ibu dalam pendidikan anak-anaknya adalah sumber dan pemberi rasa kasih sayang, pengasuh dan pemelihara, tempat mencurahkan isi hati pengatur kehidupan dalam rumah tangga, pendidik dalam segi-segi emosional.

2) Peran Ayah

Di samping ibu, peran ayah memegang peranan penting yang sangat penting pula ayah sebagai kepala keluarga merupakan penanggung jawab dalam perkembangan anak-anaknya, baik secara fisik maupun secara psikis. Dengan demikian di samping memenuhi kebutuhan secara fisik seperti makan, minum, sandang dan sebagainya, juga ayah aktif membina perkembangan pendidikan anak. ${ }^{6}$

Anak memandang ayahnya sebagai orang yang tertinggi prestasinya, berarti ayah merupakan pimpinan yang sangat patut dijadikan cermin bagi anaknya atau dengan kata lain ayah merupakan figur yang terpandai dan berwibawa. Dengan demikian, setiap perilaku ayah merupakan contoh dorongan bagi anak untuk mengikutinya orang tua harus menyadari bahwa anak selalu membutuhkan perhatian

h. 66 .

${ }^{5}$ Nursyamsiyah Yusuf, Ilmu Pendidikan (Tulungagung : Pusat Penerbitan dan Publikasi, 2000),

${ }^{6}$ Hary Hoer Aly, Ilmu Pendidikan Islam (Jakarta: Lobos Wacana Ilmu, 2009), h. 2. 
dan bimbingan orang tuanya, oleh karena itu orang tua harus mengerti betul ciri-ciri pertumbuhan yang dilalui oleh anak. Maka hal-hal yang perlu diperhatikan oleh orang tua dalam mendidik anak antara lain:

b. Kewajiban Orang Tua

Orang tua atau keluarga merupakan lingkungan pendidikan yang pertama dan utama bagi anak-anak, ${ }^{7}$ pendidikan orang tua lebih menekankan pada aspek moral atau pembentukan kepribadian dari pada pendidikan untuk menguasai ilmu pengetahuan, dasar dan tujuan penyelenggaraan pendidikan keluarga bersifat individual, sesuai dengan pandangan hidup orang tua masing-masing, sekalipun secara nasional bagi keluarga-keluarga Indonesia memiliki dasar yang sama, yaitu pancasila.

Pendidikan terhadap anak-anak menjadi tanggung jawab keluarga, sekolah, dan masyarakat. Pendidikan keluarga menempatkan ibu dan bapak sebagai pendidik kodrati. Hubungan kekeluargaan yang dekat dan didasari oleh kasih sayang serta perasaan tulus ikhlas merupakan faktor utama bagi orangtua dalam membimbing anakanaknya. Hubungan keterlibatan antara orangtua sebagai pendidik dan anak sebagai si terdidik dengan maksud bahwa orangtua mengarahkan anaknya sesuai dengan tujuannya, yaitu membantu anak memiliki dan mengembangkan dasar-dasar kemampuan yang ada pada dirinya. ${ }^{8}$

Pendidikan memiliki keterkaitan yang erat dengan proses belajar. Pendidikan memiliki cakupan yang lebih luas yang menyangkut perkembangan berbagai aspek yang ada pada diri anak, meliputi aspek sikap dan kepribadian, aspek pengetahuan, serta aspek keterampilan. Proses belajar merupakan upaya yang dilakukan dalam rangka memperoleh perubahan dan peningkatan diberbagai aspek tersebut.

Orang tua merupakan lembaga pendidikan tertua, bersifat informal, yang pertama dan utama dialami oleh anak serta lembaga pendidikan yang bersifat kodrati, orang tua bertanggung jawab memelihara, merawat, melindungi, dan mendidik anak agar tumbuh dan berkembang dengan baik. ${ }^{9}$ Bahwa perkembangan kehidupan seorang anak salah satunya ditentukan oleh orang tua, maka tanggung jawab orang tua terhadap anak sangatlah penting bagi masa depan anak, karena seorang anak pertama tumbuh dan berkembang bersama orang tua dan sesuai tugas orang tua dalam melaksanakan perannya sebagai penyelenggara pendidikan yang bertanggung jawab mengutamakan pembentukan pribadi anak. ${ }^{10}$ Dengan demikian, faktor yang mempengaruhi perkembangan pribadi anak adalah kehidupan keluarga atau orang tua beserta berbagai aspek, perkembangan anak yang menyangkut perkembangan psikologi dipengaruhi oleh status sosial ekonomi, filsafat hidup keluarga, pola hidup keluarga seperti kedisiplinan, kepedulian terhadap keselamatan dan ketertiban menjalankan ajaran agama, bahwa perkembangan kehidupan seorang anak ditentukan pula oleh faktor keturunan dan lingkungan. ${ }^{11}$

Seorang anak didalam keluarga berkedudukan sebagai anak didik dan orang tua sebagai pendidiknya, banyak corak dan pola penyelenggaraan pendidikan keluarga yang secara garis besar dapat dikelompokkan menjadi tiga kelompok pola pendidikan

\footnotetext{
${ }^{7}$ Munardji, Ilmu Pendidikan Islam, ( Jakarta : PT Bina Ilmu, 2004), h. 131.

${ }^{8}$ Moh Shochib, Pola Asuh Orang Tua dalam Membantu Anak Mengembangkan Disiplin Diri (Jakarta: Rineka Cipta, 2010), h. 21.

${ }^{9}$ Binti Maunah, Ilmu Pendidikan, (Yogyakarta : Teras : 2009), h. 92.

${ }^{10}$ Zuhairini , Filsafat Pendidikan Islam, (Jakarta : Bumi Aksara : 1991), h. 177.

${ }^{11}$ Hasbullah, Dasar-Dasar Ilmu Pendidikan ( Jakarta: PT. Raja Grafindo Persada, 2001), h. 88.
} 
yaitu, pendidikan otoriter, pendidikan demokratis, dan pendidikan liberal. ${ }^{12}$ Menurut Hamdani, ${ }^{13}$ tanggung jawab pendidikan yang perlu disadarkan dan dibina oleh kedua orangtua terhadap anaknya, antara lain: (1) Memelihara dan membesarkannya. Tanggung jawab ini merupakan dorongan alami untuk dilaksanakan karena anak memerlukan makan, minum, dan perawatan agar ia dapat hidup secara berkelanjutan. (2) Melindungi dan menjamin kesehatannya, baik secara jasmaniah maupun rohaniah dari berbagai gangguan penyakit atau bahaya lingkungan yang dapat membahayakan dirinya. (3) Mendidiknya dengan berbagai ilmu pengetahuan dan keterampilan yang berguna bagi kehidupannya kelak sehingga apabila ia telah dewasa mampu hidup mandiri dan membantu orang lain. (4) Membahagiakan anak untuk dunia dan akhirat dengan memberinya pendidikan agama sesuai dengan ketentuan Allah swt. (5) Membantu anak-anak memahami posisi dan peranannya masing-masing sesuai dengan jenis kelaminnya, agar mampu saling menghormati dan saling menolong dalam melaksanakan perbuatan baik yang diridhoi Allah swt. (6) Membantu anak didik mengenal dan memahami nilai-nilai/norma-norma yang mengatur kehidupan berkeluarga, betetangga, dan bermasyarakat dan mampu melaksanakannya untuk memperoleh ridho Allah swt. (7) Mendorong anak untuk mencari ilmu dunia dan ilmu agama agar mampu merealisasikan dirinya sebagai diri individu dan sebagai anggota masyarakat yang beriman. (8) Membantu anak-anak memasuki kehidupan bermasyarakat setahap demi setahap melepaskan diri dari ketergantungan kepada orangtua dan orang dewasa lainnya, serta mampu bertanggung jawab. (9) Membantu dan memberi kesempatan serta mendorong anak-anak mengerjakan sendiri dan berpartisipasi dalam melaksanakan kegiatan keagamaan, untuk memperoleh pengalaman sendiri secara langsung.

Kewajiban atau tanggung jawab orang tua terhadap anak-anaknya tidak hanya terbatas pada hal-hal yang sifatnya material saja melainkan juga hal-hal yang sifatnya spiritual seperti halnya pendidikan dan agama, untuk itu orang tua harus memberi teladan yang baik bagi anak-anaknya. Beberapa tanggung jawab orang tua terhadap anaknya, yaitu:

1. Pengalaman pertama masa kanak-kanak

Di dalam keluargalah anak didik mulai mengenal hidupnya, hal ini harus disadari dan dimengerti oleh setiap orang tua bahwa anak dilahirkan di dalam lingkungan keluarga yang berkembang sampai anak melepaskan diri dari ikatan keluarga, lembaga pendidikan keluarga memberikan pengalaman pertama yang merupakan faktor penting dalam perkembangan pribadi anak, suasana pendidikan keluarga ini sangat penting diperhatikan sebab dari sinilah keseimbangan individu selanjutnya ditentukan.

2. Menjamin kehidupan emosial anak

Suasana didalam keluarga harus dipenuhi dengan rasa dan simpati yang sewajarnya, suasana yang aman dan tentram juga suasana saling percaya, karena melalui keluarga kehidupan emosional atau kebutuhan kasih sayang dapat dipenuhi atau dapat berkembang dengan baik, hal ini dikarenakan ada hubungan darah antara orang tua dengan anak dan hubungan tersebut didasarkan atas rasa cinta kasih sayang yang murni, kehidupan emosional merupakan salah satu faktor yang terpenting di dalam membentuk pribadi seseorang.

\footnotetext{
${ }^{12}$ Nursyamsiyah Yusuf, Ilmu Pendidikan.....h. 52.

${ }^{13}$ Hamdani. Dasar-dasar Kependidikan (Bandung: Pustaka Setia. 2011), h. 56.
} 
3. Menanamkan dalam pendidikan moral

Di dalam keluarga juga merupakan penanaman utama dasar-dasar moral bagi anak, yang biasanya tercermin di dalam sikap dan prilaku orng tua sebagai teladan yang dapat dicontoh anak, memang biasanya tingkah laku cara berbuat dan berbicara akan ditiru oleh anak, dengan teladan ini melahirkan gejala identifikasi positif yakni penyamaan diri dengan orang yang ditiru.

4. Memberikan dasar pendidikan sosial

Keluarga merupakan basis yang sangat penting dalam peletakan dasar-dasar pendidikan sosial anak, sebab pada dasarnya keluarga merupakan lembaga sosial resmi yang minimal terdiri dari ayah, ibu, dan anak-anak, perkembangan banih-benih kesadaran sosial pada anak-anak dapat dipupuk sedini mungkin terutama lewat kehidupan keluarga yang penuh rasa tolong-menolong, gotong-royong secara kekeluargaan, menolong saudara atau tetangga sakit, bersama-sama menjaga ketertiban, kedamaian, kebersihan dan keserasian dalam menjaga hal.

\section{Peletakan dasar-dasar keagamaan}

Keluarga sebagai lembaga pendidikan pertama dan utama, disamping sangat menentukan dalam menanamkan dasar-dasar moral yang tidak kalah pentingnya adalah berperan dasar dalam proses internalisasi dan transformasi nilai-nilai keagamaan kedalam pribadi anak. Masa kanak-kanak adalah masa yang paling baik untuk meresapkan dasar-dasar hidup yang beragama, dalam hal ini tentu saja terjadi dalam keluarga, misalnya dengan mengajak anak ikut serta kemasjid untuk menjalankan ibadah, mendengarkan khutbah atau ceramah keagamaan, kegiatan seperti ini besar sekali pengaruhnya terhadap kepribadian anak, jadi kehidupan dalam keluarga hendaknya memberikan kondisi kepada anak untuk mengalami suasana hidup keagamaan. ${ }^{14}$ Dalam bidang pendidikan utama dan dalam bidang ekonomi orang tua merupakan produsen dan konsumen sekaligus harus mempersiapkan dan memberikan segala kebutuhan sehari-hari, seperti sandang dan pangan, dengan fungsinya yang ganda orang tua mempunyai peranan yang besar dalam mensejahterakan keluarga, oleh karena itu orang tua bertanggung jawab atas keluarganya baik dalam bidang ekonomi maupun bidang pendidikan.

Keluarga sebagai pusat pendidikan utama dan pertama yaitu Keluarga (orang tua) merupakan pendidik pertama bagi anak-anak karena dari merekalah anak mulamula menerima pendidikan, dengan demikian bentuk pertama dari pendidikan itu terdapat dalam kehidupan keluarga. Orang tua yaitu ayah dan ibu yang mempunyai peranan penting dan sangat berpengaruh atas pendidikan anak-anaknya, sejak seorang anak lahir seorang ibunyalah yang selalu disampingnya. ${ }^{15}$

Berkaitan dengan masalah pendidikan, maka orang tua atau keluarga merupakan tempat untuk meletakkan pondasi dasar pendidikan bagi anak-anaknya, maksudnya pendidikan dilingkungan keluarga merupakan peletakan dasar bagi perkembangan anak untuk selanjutnya, dengan demikian lingkungan yang diciptakan oleh orang tuanyalah yang menentukan masa depannya, oleh karena itu orang tua berkewajiban untuk menciptakan lingkungan keluarga yang harmonis dan

\footnotetext{
${ }^{14}$ Hasbullah, Dasar-dasar Ilmu Pendidikan ...h 38-39

${ }^{15}$ Zakiah, Ilmu Pendidikan Islam (Jakarta : Bumi Aksara, 2008), h. 35.
} 
berkewajiban memberikan didikan dan bimbingan kepada anak-anak, sebab merekalah yang mempunyai tanggung jawab terhadap pendidikan anak-anak. ${ }^{16}$

Dasar-dasar tanggung jawab keluarga atau orang tua dalam mendidik anak, yaitu:

a) Adanya motivasi atau dorongan cinta kasih yang menjiwai hubungan orang tua dan anak, kasih sayang orang tua yang ikhlas dan murni akan mendorong sikap dan tindakan rela dan menerima tanggung jawab untuk mengorbankan hidupnya dalam memberi pertolongan kepada anaknya.

b) Pemberian motivasi kewajiban moral sebagai konsekwensi kehidupan orang tua terhadap keturunannya, adanya tanggung jawab moral ini meliputi nilai-nilai spiritual, menurut para ahli bahwa penanaman sikap beragama sangat baik pada masa anak-anak. Karena seorang anak memiliki pengalaman agama yang asli dan mendalam, serta mudah berakar dalam diri dan kepribadiannya, hal tersebut merupakan faktor yang sangat penting melebihi orang lain, karena pada saat ini anak mempunyai sifat wondering (heran) sebagai salah satu faktor untuk memperdalam pemahaman spiritual reality, pada periode ini peranan orang tua sering mengajak anak-anaknya ketempat-tempat ibadah sebagai penanaman dasar yang akan mengarahkan anak pada pengabdian yang selanjutnya, dan mampu menghargai kehadiran agama dalam bentuk pengalaman dengan penuh ketaatan. Dengan demikian, penanaman agama yang dimiliki anak sejak kecil ini betul-betul tertanam dan berkesan pada dirinya.

c) Tanggung jawab sosial adalah bagian dari keluarga yang pada gilirannya akan menjadi tanggung jawab masyarakat, bangsa dan Negara. Tanggung jawab sosial itu merupakan perwujudan kesadaran tanggung jawab kekeluargaan yang dibina oleh darah, keturunan, dan kesatuan keyakinan.

d) Memelihara dan membesarkan anaknya, tanggung jawab ini merupakan dorongan alami untuk dilaksanakan karena anak memerlukan makan, minum dan perawatan agar ia dapat hidup secara berkelanjutan.

e) Memberikan pendidikan dengan berbagai ilmu pengetahuan dan ketrampilan yang berguna bagi kehidupan anak kelak, sehingga bila ia dewasa akan mampu mandiri. ${ }^{17}$

Dengan demikian, terlihat besar tanggung jawab orang tua terhadap anak. Bagi seorang anak, keluarga persekutuan hidup pada lingkungan keluarga tempat dimana ia menjadi diri pribadi atau diri sendiri, keluarga juga merupakan wadah bagi anak dalam konteks proses belajarnya untuk mengembangkan dan membentuk dari dalam fungsi sosialnya.

Setiap orang menginginkan agar keturunannya dapat dibanggakan dan dapat membahagiakan orang tua dunia akhirat, oleh karena itu keseimbangan antara orang tua dan anak harus dilaksanaknan sebaik-baiknya. Dalam Al-Qur'an umat Islam diperintahkan untuk lebih mengutamakan kerabatnya dalam memberikan perhatian.

Dalam Firman Allah dalam QS. al-Jaastiyah/45:13-14:

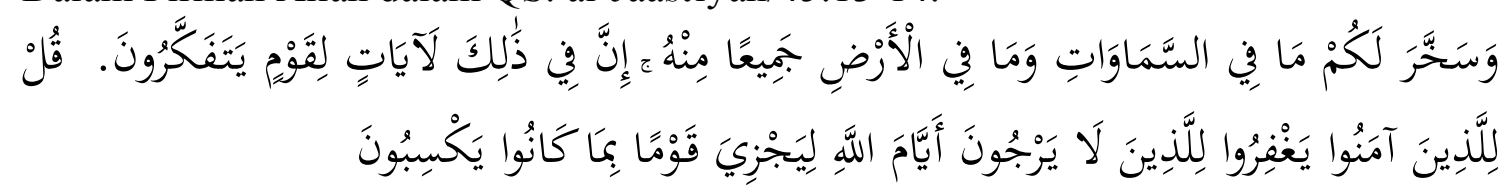

\footnotetext{
${ }^{16}$ Dalyono, Psikologi Pendidikan (Jakarta : PT. Rineka Cipta, 2007), h. 59

${ }^{17}$ Binti Maunah, Ilmu Pendidikan ... h. 100
} 
Terjemahnya:

Dan Dia telah menundukkan untukmu apa yang di langit dan apa yang di bumi semuanya, (sebagai rahmat) daripada-Nya. Sesungguhnya pada yang demikian itu benar-benar terdapat tanda-tanda (kekuasaan Allah) bagi kaum yang berfikir.

Katakanlah kepada orang-orang yang beriman hendaklah mereka memaafkan orang-orang yang tiada takut hari-hari Allah. Karena dia akan membalas sesuatu kaum terhadap apa yang Telah mereka kerjakan.

Dalam keluarga terdapat hubungan timbal balik antara orang tua dan anak yang mana kewajiban orang tua menjadi hak bagi anak-anaknya dan begitu juga sebaliknya, kewajiban anak merupakan hak bagi orang tua. Maka perlu dijelaskan bahwa fungsi keluarga, yakni:

1. Fungsi pengaturan seksual

Orang tua atau Keluarga adalah lembaga pokok yang merupakan wahana bagi masyarakat untuk mengatur dan mengorganisasikan keinginan seksual, kehidupan sosial yang teratur dan terlindungi nyata-nyata menjadi pilihan hidup manusia. Dorongan-dorongan seksual yang perlu mendapatkan penyaluran diupayakan untuk difasilitasi antara individu yang memiliki kecenderungan dan komitmen untuk saling memenuhi kebutuhan satu sama lain, penyaluran yang terorganisir yang relatif bisa dikomunikasikan dan mendapatkan pengakuan dari individu lain adalah dengan cara membentuk keluarga.

2. Fungsi reproduksi

Salah satu akibat dari hubungan seksual adalah mendapatkan keturunan. Dengan demikian, dalam keluarga terdapat fungsi reproduksi. Fungsi reproduksi ini luga bisa dikatakan sebagai fungsi regenerasi dimana pasangan dalam keluarga berkeinginan untuk melanjutkan generasi yang tumbuh dengan hak-hak dan kewajiban keluarga yang bersangkutan. Terdapat cara lain dimana masyarakat yang menetapkan seperangkat norma untuk memperoleh anak selain sebagai bagian dari keluarga.

3. Fungsi sosialisasi

Sebagaimana diketahui secara faktual bahwa anak dilahirkan dalam keadaan suci, sehingga evolusi perkembangan biologis dan psikologisnya memerlukan proses sosialisasi dari orang-orang terdekatnya, bahkan keluarga juga menjadi tempat sosialisasi bagi orang-orang dewasa, dimana satu sama lain bisa memberi dan menerima seperangkat pola berperilaku yang diinginkan satu sama lain. Sosialisasi ini menjadi penting ketika anak sudah cukup umur untuk memasuki kelompok lain diluar keluarga, pondasi dasar kepribadiannya sudah ditanamkan secara kuat, salah satu dari sekian banyak cara keluarga untuk mensosialisasikan anak adalah melalui pemberian model bagi anak.

4. Fungsi afeksi

Salah satu kebutuhan dasar manusia adalah kebutuhan akan kasih sayang atau rasa dicintai, dengan demikian ketiadaan afeksi akan mempengaruhi kemampuan seorang bayi untuk bertahan hidup, sehingga logis ketika mengatakan bahwa kebutuhan akan persahabatan dan keintiman, tanggapan manusiawi yang penuh kasih sayang penting adanya bagi manusia, barangkali cinta adalah salah satu kebutuhan sosial kita yang paling penting, jauh lebih penting misalnya seks, banyak orang yang 
tidak menikah namun bisa bahagia, sehat, dan hidup berguna, tetapi orang yang tidak pernah dicintai jarang bahagia dan tidak berguna.

5. Fungsi penentuan status

Dalam memasuki sebuah keluarga, seseorang mewarisi suatu rangkaian status, seseorang diserahi beberapa status dalam keluarga berdasarkan umur, jenis kelamin, urutan kelahiran, dan lain-lain. Dalam masyarakat yang berdasarkan system kelas, status kelas keluarga seorang anak sangat menentukan peluang dan hadiah yang terbuka untuk itu dan harapan yang dapat digunakan orang lain untuk mendorong atau merintangi. Namun demikian, status kelas dapat diubah melalui beberapa cara seperti karena faktor keberuntungan dan usaha pribadi yang dalam sosiologi biasanya dibahas dalam konteks mobilitas sosial. Pada dasarnya, setiap anak mulai dengan status kelas keluarganya, dan ini sangat mempengaruhi prestasi dan imbalan yang akan diterimanya.

6. Fungsi perlindungan

Dalam setiap masyarakat, orang tua atau keluarga memberikan perlindungan fisik, ekonomis, dan psikologis bagi seluruh anggotanya. Keluarga akan memberikan peluang-peluang bahkan menghindarkan rintangan yang akan mengganggu sebagian anggota keluarganya untuk mendapatkan hak perlindungan fisik, ekonomis dan psikologis. Biasanya anggota keluarga akan saling merasakan kebahagiaan atau penderitaan anggota-anggotanya satu sama lain, kebahagiaan salah seorang anggota keluarga akan menimbulkan rasa puas terhadap anggota keluarga yang lain. Demikian pula, aib atau rasa malu yang ditimbulkan oleh salah seorang anggota keluarga biasanya akan menimbulkan rasa kecewa dan hinanya anggota keluarga yang lainnya.

7. Fungsi ekonomis

Seperti dijelaskan di atas bahwa keluarga merupakan unit ekonomi yang akan memberikan kebutuhan-kebutuhan ekonomi seluruh anggota keluarganya, para anggota keluarga bekerja sama sebagai team untuk menghasilkan sesuatu yang secara ekonomis berguna untuk kelangsungan hidup untuk seluruh anggota keluarganya.

Pentingnya keluarga dalam kehidupan masyarakat Sosiologi telah dijelaskan di atas, sementara dalam sudut pandang pendidikan ada beberapa penegasan yang perlu dibuat terkait posisi keluarga yang menjadi lembaga pendidikan yang pertama dan utama. Dengan demikian, keluarga diharapkan menyediakan lingkungan yang kondusif dan sekaligus sebagai sarana yang efektif untuk terjadinya proses pembelajaran.

Secara Sosiologis keluarga adalah bentuk masyarakat terkecil dan merupakan kelompok sosial yang pertama dimana anak menjadi anggotanya serta menjadi tempat anak untuk menjadikan sosialisasi kehidupan anak-anak tersebut. Ibu, ayah, dan saudara serta keluarga-keluarga yang lain adalah orang yang pertama dimana seorang anak mengadakan kontak pertama untuk mendidik atau mengajar pada anak itu sebagaimana dia hidup dengan orang lain, sampai anak-anak memasuki sekolah mereka itu dan menghabiskan seluruh waktunya di dalam unit keluarga, hingga sampai pada remaja mereka itu kira-kira menghabiskan setengah waktunya dalam keluarga. ${ }^{18}$

Setiap orang tua ingin membina anak agar menjadi anak yang baik mempunyai kepribadian yang kuat dan sikap mental yang sehat serta akhlak yang terpuji. Orang tua adalah pembina pribadi yang pertama dalam hidup anak. Setiap pengalaman yang

\footnotetext{
${ }^{18}$ Nursyamsiyah Yusuf, Ilmu Pendidikan ... h. 65.
} 
dilalui anak, baik melalui penglihatan, pendengaran maupun perilakuan yang diterimanya akan ikut menentukan pembinaan pribadinya.

Acapkali orang tua yang tidak sengaja, tanpa di sadari mengambil suatu sikap tertentu, anak melihat dan menerima sikap orang tuanya dan memperhatikan suatu reaksi dalam tingkah lakunya yang dibiasakan, sehingga akhirnya menjadi suatu pola kepribadian. Kepribadian orang tua, sikap dan cara hidup mereka merupakan unsurunsur pendidikan yang tidak langsung, yang dengan sendirinya akan masuk ke dalam pribadi anak yang sedang tumbuh. ${ }^{19}$ Di sini tugas orang tua unt uk menjadi pembimbing anaknya, supaya perkembangan anak yang dialami pada permulaan hidup dapat berlangsung sebaik-baiknya, tanpa gangguan yang berarti.

Hubungan orang tua sesama anak sangat mempengaruhi pertumbuhan jiwa anak. Hubungan yang serasi, penuh pengertian dan kasih sayang akan membawa anak kepada pembinaan pribadi yang tenang, terbuka dan mudah dididik, karena anak mempunyai kesempatan yang baik untuk tumbuh berkembang. Hubungan yang sangat erat yang terjadi dalam pergaulan sehari-hari antara orang tua dan anak merupakan hubungan berarti yang diikat pula oleh adanya tanggung jawab yang benar sehingga sangat memungkinkan pendidikan dalam keluarga dilaksanakan atas dasar rasa cinta kasih sayang yang murni, rasa cinta kasih sayang orang tua terhadap anaknya. ${ }^{20}$

Tetapi hubungan orang tua yang tidak serasi, banyak perselisihan dan percekcokan akan membawa anak kepada pertumbuhan pribadi dan tidak dibentuk, karena anak tidak mendapat suasana yang baik untuk berkembang, sebab selalu terganggu oleh suasana orang tuanya. Dan banyak lagi faktor-faktor tidak langsung dalam keluarga yang mempengaruhi pembinaan pribadi anak. Di samping itu, banyak pula pengalaman-pengalaman yang mempunyai nilai pendidikan baginya, yaitu pembinaan-pembinaan tertentu yang dilakukan oleh orang terhadap anak, baik melalui latihan-latihan atau pembiasaan, semua itu merupakan unsur pembinaan pribadi anak.

\section{METODOLOGI PENELITIAN}

Penelitian ini bersifat deskriptif dengan lokasi penelitian pada Sekolah Dasar Negeri 325 Polewalie Kecamatan Gilireng Kabupaten Wajo. Pendekatan yang digunakan adalah pendekatan pedagogis dan psikologis. Data diperoleh melalui metode wawancara dan dokumentasi dengan instrumen penelitian adalah pedoman wawancara dan alat dokumentasi seperti kamera dan flasdish. Aktifitas dalam analisis meliputi reduksi data (data reduction), penunjukan data (display daya) serta penarikan kesimpulan dan verifikasi (conclusion drawing/verificatiori). Data diuji keabsahannya dengan cara melakukan perpanjangan pengamatan, peningkatan ketekunan, dan triangulasi yang mencakup triangulasi sumber dan triangulasi teknik.

\section{HASIL PENELITIAN DAN PEMBAHASAN}

Berdasarkan observasi yang telah dilakukan, maka saya menemukan tentang kontribusi orang tua dan pendidik yang sangat dibutuhkan oleh peserta didik demi kelancaran pembelajaran sehingga akan berdampak positif. Untuk memperjelas hasil pengamatan yang telah dilakukan maka saya melakukan wawancara secara mendalam

\footnotetext{
${ }^{19}$ Sumadi,Suryabrata, Psikologi Kepribadian (Jakarta: PT. Raja Grafindo Persada, 2000), h. 43.

${ }^{20}$ Hasan Langgulung, Pendidikan Islam dalam Menghadapai Abad ke 21 (Jakarta: Pustaka Al Husna. 2008), h. 32.
} 
kepada salah seorang orang tua srta didik. Berikut hasil wawancara dengan Muh. Yusuf, beliau menyatakan bahwa:

Setiap orang tua mengharapkan seorang anak yang sukses. Banyak cara yang dapat ditempuh untuk menccapai tujuan tersebut. Namun, dalam menjalankanya ada yang berhasil ada juga yang tidak. Bimbingan adalah salah satu cara yang dapat digunakan untuk mencapai tujuan tersebut. Bimbingan sebenarnya harus dilakukan oleh anggota keluarga atu orang tua, karena orang tua adalah lingkungan hidup pertama yang mempengaruhi jalan hidup anak. Keluarga adalah lingkungan social terkecil tetapi peranannya sangat besar. Dalam mendapatkan sebuah prestasi kegiatan yang wajib dilaksanakan anak adalah belajahar. Dalam hal ini orang tua sangat berperan penting, karena orang tua mempunyai tanggung jawab untuk memotivasi anak dalam belajar serta membimbingnya. Dalam hal tersebut maka akan menjadikan anak untuk memperhatikan apa yang harus dikerjakannya. Karena orang tuanya selalu memperhatikan apa yang harus dipelajarinya. $^{21}$

Berikut pemaparan yang diperoleh dari Ibu Hanafizah selaku pndidik sekaligus sebagai kepala sekolah, bahwa:

Orang tua atau ibu dan ayah memegang peranan yang penting dan sangat berpengaruh atas pendidikan anak-anaknya. Sejak seorang anak dilahirkan ibunya yang selalu ada disampingnya. Hal ini menunjukkan tanggung jawab setiap orang tua atas kehidupan anak-anak mereka untuk masa kini dan mendatang. Bahkan para orang tua umumnya merasa tanggung jawab atas segalanya dari kelangsungan hidup anak-anak mereka. Karenanyalah tidak diragukan bahwa tanggung jawab pendidikan secara mendasar terpaku kepada orang tua. Apakah tanggung jawab pendidikan itu diakuinya secara sadar atau tidak, hal ini adalah merupakan "fitrah" yang telah dikodratkan Allah swt, kepada setiap orang tua. Maka tidak bisa mengelakkan tanggung jawab itu karena telah merupakan amanah Allah swt. yang dibebankan kepada mereka. ${ }^{22}$

Hal serupa juga dipaparkan oleh Ibu Andi Intang selaku pendidik kelas II, bahwa:

Kami selalu mengundang orang tua siswa setiap akhir semester untuk menerima rapor anaknya dan membahas hasil belajar siswa apakah itu hasil belajar siswa menurun atau meningkat, kemudian memberikan arahan-arahan kepada orang tua siswa agar selalu membimbing anaknya di rumah dan guru agar kiranya dapat membimbing siswa di sekolah untuk meningkatkan prestasi belajar yang lebih baik. Dan mengadakan surat menyurat antara orang tua siswa dengan guru dan kepala sekolah. $^{23}$

Berdasarkan hal tersebut, peneliti mendapatkan penjelasan dari Ibu Parmi yaitu pendidik kelas III yang menyatakan bahwa:

Anak adalah tanggung jawab orang tua, terutama dalam pendidikannya. Oleh karena itu, orang tua harus selalu memberikan fasilitas untuk anak dalam melancarkan pendidikannya. Selain itu, orang tua juga harus mendampingi dan mengarahkan pada anak, terutama dalam hal belajar. ${ }^{24}$

\footnotetext{
${ }^{21}$ Muh. Yusuf, Orang Tua Peserta Didik, Wawancara, di kediaman Muh. Yusuf.

${ }^{22}$ Hanafizah, Kepala SDN 325 Polewalie, Wawancara, di ruangan kepala sekolah.

${ }^{23}$ Andi Intang, Pendidik Kelas III, Wawancara, di SDN 325 Polewalie.

${ }^{24}$ Parmi, Pendidik Kelas III, Wawancara, di SDN 325 Polewalie.
} 
bahwa:

Kemudian pada kesempatan lain saat Ibu Darnawati yang ditemui menjelaskan

Peran orang tua dalam memberikan semangat belajar pada anak sangat penting, karena anak-anak Jika tidak dimotivasi belajarnya maka akan sulit atau bahkan mereka tidak akan pernah belajar. Agar anak mau belajar, tahap awal harus berangkat dari orang tua yang harus selalu memberikan nasehat dan mendampinginya dalam belajar. Anak Jika Cuma disuruh aja tidak akan belajar Jika orang tuanya tidak bertindak untuk ikut mendampinya belajar. ${ }^{25}$

Pemaparan tersebut dipertegas oleh Bapak Muh. Saleng salah satu orang tua peserta didik yang menyatakan bahwa:

Anak harus dibiasakan dari kecil untuk belajar secara rutin, walau sebentar. Untuk membiasakan anak terus belajar, maka orang tua harus ikut belajar, ikut mendampinginya sehingga anak itu tidak sendiri, dia akan merasa diperhatikan dan merasa bahwa orang tuanya sangat menyayanginya. Orang tua juga harus memberikan motivasi melalui pemenuhan kebutuhan atau fasilitas dalam belajar, sehingga anak tidak merasa kesulitan karena fasilitas yang kurang lengkap atau kurang memadai. Kami sebagai orang tua mempunyai kewajiban dalam membimbing anak agar mampu mempunyai prestasi yang baik di sekolah. Kami tetap meluangkan waktu untuk mengawasi dan memberikan nasihat untuk selalu belajar secara teratur. ${ }^{26}$

Begitu pula halnya penjelasan yang diperoleh dari hasil wawancara dengan Ibu Jumerang salah satu orang tua peserta didik, bahwa:

Dalam hal pelajaran bagi anak itu nomer satu bagi kami, kami menginginkan anakanak kami mempunyai prestasi yang baik di sekolah, karena ini akan menjadi kebanggan tersendiri bagi kami selaku orang tua. Oleh karena itu kami pun harus turut serta mendidik anak-naak kami. ${ }^{27}$

Dari keterangan yang peneliti dapat dari Bapak Nunggu yang mengatakan bahwa:

Selaku orang tua, kami berkewajiban membimbing dan mendidik anak sehingga akan mempunyai prestasi yang baik di sekolah. Sudah kewajiban orang tua untuk selalu mendidik dan membimbing anak agar anak mempunyai prestasi belajar yang baik di sekolah, bukan hanya dididik oleh guru. ${ }^{28}$

Hasil wawancara yang dilakukan peneliti terhadap salah seorang orang tua peserta didik sebagai berikut :

Anak adalah titipan Allah swt. jadi kami mempunyai kewajiban untuk mendidik dan membina anak agar dapat berprestasi di sekolahnya. Kami bersyukur anak kami mempunyai prestasi yang baik dan di sekolah masuk dalam 3 besar, kami berusaha untuk selalu membimbing anak agar dapat belajar dengan tekun dan mempunyai prestasi yang baik di sekolah. ${ }^{29}$

Pendapat lain dikemukakan oleh salah seorang ibu yang dapat dilihat pada hasil wawancara sebagai berikut :

\footnotetext{
${ }^{25}$ Darnawati, Orang Tua Peserta Didik SDN 325 Polewalie, Wawancara, di rumah.

${ }^{26}$ Muh. Saleng, Orang Tua Peserta Didik SDN 325 Polewalie, Wawancara, di rumah.

${ }^{27}$ Jumerang, Orang Tua Peserta Didik SDN 325 Polewalie, Wawancara, di rumah

${ }^{28}$ Nunggu, Orang Tua Peserta Didik SDN 325 Polewalie, Wawancara, di rumah.

${ }^{29}$ Hasnawati, Orang Tua Peserta Didik SDN 325 Polewalie, Wawancara, di rumah.
} 
Saya sebagai ibu di rumah wajib memberikan bimbingan pada anak agar dia mempunyai hasil belajar yang baik di sekolah. Itu sudah kewajiban kami selaku orang tua untuk selalu mendidik dan mengajari anak agar mempunyai prestasi belajar yang baik, karena itu juga demi masa depan anak kami juga. ${ }^{30}$

Hal senada dikemukakan oleh seorang peserta didik ditengah-tengah kegiatan belajarnya, yang dapat dilihat pada hasil wawancara sebagai berikut :

Pemberian semangat atau motivasi dari orang tua kepada anaknya dalam upaya menciptakan kesungguhan belajar anak akan berhasil bila pihak orang tua selalu mendampingi anak dalam belajar, atau ketika anak belajar sendiri, orang tua tidak lupa untuk memantaunya. Jika suasana belajar dalam rumah sudah tercipta dengan baik maka anak pun dengan senang hati akan belajar tanpa menunggu untuk disuruh atau diiming-imingi hadiah. Akan tetapi jangan lupa, bahwa menyuruh anak untuk

Hasil wawancara dengan salah seorang orang tua peserta didik di sela-sela ksibukan sebagai ibu rumah tangga sebagai berikut:

Belajar atau memberikan hadiah sebagai bentuk motivasi kepada anak untuk belajar tetap harus dilakukan. Pemberian motivasi oleh orang tua merupakan sebuah usaha meningkatkan belajar anak yang sekaligus sebagai bentuk kepedulian pada anak atau bentuk kasih sayang dan tanggung jawab orang tua terhadap anak. Setiap anak yang lahir ke dunia, pertama-tama diasuh dan dididik oleh orang tuanya. Orang tua sebagai peletak dasar pendidikan yang akan menentukan arah dan tujuan pendidikan yang akan dicapai oleh anak, baik menyangkut kehidupan keagamaan maupun kehidupan dunia. ${ }^{31}$

Wawancara yang dilakukan peneliti terhadap salah seorang orang tua peserta didik tentang pentingnya peran orang tua adalah sebagai berikut:

Rumah tangga atau keluarga adalah taman kanak-kanak yang mempunyai pengaruh yang sangat besar terhadap proses belajar anak. Kegagalan mendidik dalam lingkungan keluarga merupakan malapetaka bagi kehidupannya kelak. Oleh karena itu, dapat dikatakan orang tua sangat berperan dalam proses belajar anak, di mana penanggung jawab terhadap anak sebagai anggota keluarga adalah orang tua yang akan memberikan corak hidup dan kehidupan di dunia ini, dan orang tua yang menentukan apakah anak itu akan dijadikan anak yang terpelajar. Orang tua perlu memberikan bimbingan dan arahan dalam setiap aktifitas belajar anak. Orang tua diharapkan dapat memberikan motivasi pada anak dalam meningkatkan belajarnya. ${ }^{32}$

Sedangkan menurut penuturan seorang Ibu dari peserta didik yang lain bahwa: Dengan adanya motivasi orang tua, berarti adanya keterlibatan orang tua dalam aktifitas belajar anak. Jadi anak tidak dibiarkan belajar dengan sendirinya, akan tetapi terus didampingi dan dipantau aktifitas belajarnya. Dengan begitu, anak akan merasa ditemani dan dihargai dalam belajarnya, sehingga akan tumbuh semangat dalam dirinya untuk terus belajar dan belajar. ${ }^{33}$

\footnotetext{
${ }^{30}$ Isia, Orang Tua Peserta Didik SDN 325 Polewalie, Wawancara, di rumah.

${ }^{31}$ Hasnawati, Orang Tua Peserta Didik SDN 325 Polewalie, Wawancara, di rumah.

${ }^{32}$ Samsu, Orang Tua Peserta Didik SDN 325 Polewalie, Wawancara, di rumah.

${ }^{33}$ Rusli, Orang Tua Peserta Didik SDN 325 Polewalie, Wawancara, di rumah.
} 
Hal senada dikemukakan oleh Ibu Herlina disela-sela aktifitas di rumah sebagai ibu rumah tangga sebagai berikut:

Betapa pentingnya peran motivasi orang tua dalam menumbuhkan semangat belajar bagi anak sehingga anak dapat melakukan kegiatan belajar dengan sungguh -sungguh. Untuk mewujudkan itu semua, yang tidak boleh ditinggalkan oleh orang tua bahwa orang tua harus bisa memahami keinginan dan kebutuhan belajar anak, sehingga motivasi yang diberikan akan bisa membangkitkan semangat anak dalam belajar karena motivasi yang diberikan tepat sasaran. Seperti anak ingin belajar dalam suasana yang sunyi atau sambil nonton TV, kebutuhan belajar yang lengkap, atau juga keinginan anak untuk didampingi dalam belajar atau ingin belajar sendiri. Semua itu harus bisa dipahami oleh orang tua agar anak bisa belajar dengan sungguh-sungguh. ${ }^{34}$

Hal ini didukung dengan adanya wawancara dengan Bapak Rusman selaku orang tua peserta didik mengatakan bahwa:

Orang tua memiliki cara dan pola tersendiri dalam mengasuh dan membimbing anak. Cara dan pola tersebut pasti berbeda antara satu keluarga dengan keluarga yang lainnya. Pola dan cara tersebut merupakan gambaran tentang sikap dan perilaku orang tua dan anak dalam berinteraksi, berkomunikasi selama mengadakan kegiatan pembimbingan. Adapun hal-hal yang diberikan orang tua dalam membimbing anak adalah memberikan perhatian, peraturan, disiplin, hadiah dan hukuman, serta tanggapan terhadap anaknya. Dengan hal-hal tersebut maka akan diharapkan semangat belajar anak naik dan menjadikan prestasi yang unggul. ${ }^{35}$

Berikut hasil wawancara dengan Ibu Munawarah salah sorang ibu rumah tangga skaligus ibu dari salah satu serta didik di SDN 325 Polewalie:

Peran serta orang tua hendaknya sedini mungkin diterapkan pada anak-anak mereka, ini bertujuan untuk meningkatkan prestasi anak-anak agar menjadi pribadi yang maju dan bertanggung jawab. Seberat apapun permasalahan mereka pasti dapat dilalui apabila mendapat dukungan dan bantuan dari orang tua. Sebagai orang tua hendaknya menanamkan semangat dan disiplin kepada anakanak mereka agar dapat berprestasi di sekolah dan kedisiplinan menjadi kunci untuk mencapai keberhasilan. Kemandirian bukan berarti tanpa dukungan dari orang lain, namun kemandirian adalah usaha untuk menjalankan atau melaksanakan segala pekerjaan dengan mengandalkan kemampuan sendiri dengan dukungna dan dorongan dari orang lain. ${ }^{36}$ bahwa:

Senada dengan hal tersebut, Bapak Abd. Rahman juga memberikan pernyataan

Saya selalu membantu anak menyelesaikan pekerjaan rumah yang diberikan oleh guru di sekolah sesuai dengan kemampuan saya dengan cara saya selalu menanyakan kepada anak "apakah anak punya PR besok atau tidak" dan ketika ada maka saya mendampingi anak selama anak mengerjakan PR tersebut sampai selesai. Dan ketika ada pertanyaan yang tidak diketahui jawabannya secara langsung maka saya mengarahkan kepada guru pembimbingnya. Karena selain

\footnotetext{
${ }^{34}$ Herlina, Orang Tua Peserta Didik SDN 325 Polewalie, Wawancara, di rumah.

${ }^{35}$ Rusman, Orang Tua Peserta Didik SDN 325 Polewalie, Wawancara, di rumah.

${ }^{36}$ Munawarah, Orang Tua Peserta Didik SDN 325 Polewalie, Wawancara, di rumah.
} 
belajar di sekolah saya juga memberikan bimbingan di luar jam belajar di sekolah. ${ }^{37}$ bahwa:

Seorang pendidik yaitu Ibu Nelly juga memberikan pernyataan kepada peneliti

Dalam proses belajar mengajar siswa, faktor kesehatan sangat mempengaruhi proses belajar siswa, apa lagi kalau siswa dalam keadaan cacat. Jadi, ketika ada siswa yang kurang sehat dalam belajar maka siswa tidak diikutkan dalam proses belajar mengajar, dan orang tua harus membuat surat sakit untuk anaknya. Demikia juga guru. ${ }^{38}$

Berdasarkan hasil wawancara yang dilakukan dengan pendidik SDN 325 Polewalie yang menyatakan bahwa:

Sebagian orang tua siswa kurang memperhatikan anaknya misalnya dalam mendidik orang tuanya itu acuh tak acuh terhadap belajar anaknya, bahkan ada yang tidak memperhatikan perlengkapan sekolah anaknya seperti alat tulis menulis, pakaian sekolah anaknya. Sehingga anaknya pergi sekolah dengan apa adanya. Padahal semua itu faktor yang dapat menghambat proses belajar siswa. sebagian orang tua juga ekonominya kurang sehingga tidak mampu dalam memenuhi kebutuhan pokok anaknya misalnya memberikan makanan yang bergizi, membelikan pakaian. Jadi, kalau di bandingkan sebagian besar orang tua mampu dalam memenuhi kebutuhan pokok anakanaknya. ${ }^{39}$

Berdasarkan observasi yang dilakukan pada tanggal 20 September 2017, diketahui bahwa pendidik sangat memperhatikan model pembelajaran yang digunakan untuk mencapai hasil pembelajaran yang maksimal. Berikut wawancara dengan Muh. Safaruddin yang mengatakan bahwa:

Dalam melaksanakan pembelajaran guru dituntut untuk menguasai materi pembelajaran yang akan diberkan. Selain itu dalam proses pembelajaran guru juga harus mampu mengondisikan kelas agar proses pembelajaran dapat berlangsung optimal. Agar upaya tersebut berhasil dilakukan guru harus mampu mengelola diskusi kelas menggunakan alat peraga dan menggunakan metode yang bervariatif. Mengelolah pembelajaran dengan baik dan profesional sehingga dapat menciptakan susana yang menyenangkan. karena apabila anak senang maka besar kemauannya memperhatikan terhadap tugas yang diberikan. sehingga hasil belajar anak dapat meningkat, maka dari itu guru dalam mengajar hendaknya tidak membuat anak takut salah, takut ditertawai, dan takut dianggap sepele.

Pendidik memberikan pernyataan kepada peneliti saat ditemui dalam wawancara mengatakan bahwa:

Sebagian orang tua siswa kurang memperhatikan anaknya misalnya dalam mendidik orang tuanya itu acuh tak acuh terhadap belajar anaknya, bahkan ada yang tidak memperhatikan perlengkapan sekolah anaknya seperti alat tulis menulis, pakaian sekolah anaknya. Sehingga anaknya pergi sekolah dengan apa adanya. Padahal semua itu faktor yang dapat menghambat proses belajar siswa. ${ }^{40}$

\footnotetext{
${ }^{37}$ Abd. Rahman Orang Tua Peserta Didik SDN 325 Polewalie, Wawancara, di rumah.

${ }^{38}$ Nelly, Pendidik Kelas VI SDN Polewalie, Wawancara, di Ruang Guru.

${ }^{39}$ Nirwana, Pendidik Kelas IV SDN Polewalie, Wawancara, di Ruang Kelas IV

${ }^{40}$ Nurmiati, Pendidik Kelas I SDN 325 Polewalie, Wawancara, di ruang kelas.
} 
Hal ini dipertegas dengan pernyataan kepala SDN 325 Polewalie yang menjelaskan bahwa:

Sebagai kepala sekolah saya selalu mengundang orang tua siswa setiap akhir semester untuk menerima rapor anaknya dan membahas hasil belajar siswa apakah itu hasil belajar siswa menurun atau meningkat, kemudian memberikan arahan-arahan kepada orang tua siswa agar selalu membimbing anaknya di rumah dan guru agar kiranya dapat membimbing siswa di sekolah untuk meningkatkan prestasi belajar yang lebih baik. Dan mengadakan surat menyurat antara orang tua siswa dengan guru dan kepala sekolah. $^{41}$

\section{PENUTUP}

Berdasarkan paparan di atas, maka dapat disimpukan bahwa kontribusi antara orang tua dan pendidik dalam meningkatkan prestasi belajar dapat meningkatkan belajar anak di sekolah, sangat ditentukan oleh kerja sama orang tua dan pendidik karena pedidikan merupakan usaha untuk mendewasakan orang yang belum dewasa sehingga mampu berdiri sendiri sebagai manusia dewasa yang penuh ilmu pengetahuan.

Sebagai implikasi dari penelitian ini adalah orang tua lebih memperhatikan potensi dan kreativitas yang dimiliki anak dan memberikan dukungan dan motivasi kepada anak dengan menciptakan suasana pembelajaran dirumah yang dapat mengasah potensi dan kreativitas pada anak.

\footnotetext{
${ }^{41}$ Hanafizah, Kepala SDN 325 Polewalie, Wawancara, di ruangan kepala sekolah
} 


\section{DAFTAR PUSTAKA}

Aly, Hary Hoer, Ilmu Pendidikan Islam, Jakarta: Lobos Wacana Ilmu, 2009.

Dalyono, Psikologi Pendidikan, Jakarta : PT. Rineka Cipta, 2007.

Hamdani, Dasar-dasar Kependidikan, Bandung: Pustaka Setia. 2011.

Harini, Sri, Mendidik Anak Sejak Dini, Yogyakarta: Kreasi Wacana, 2003.

Hasbullah, Dasar-Dasar Ilmu Pendidikan, Jakarta: PT. Raja Grafindo Persada, 2001.

Langgulung, Hasan, Pendidikan Islam dalam Menghadapai Abad ke 21, Jakarta: Pustaka Al Husna. 2008.

Maunah, Binti, Ilmu Pendidikan, Yogyakarta: Teras, 2009.

Moeliono, Anton, Kamus besar bahasa Indonesia, Jakarta : Balai Pustaka, 1989.

Munardji, Ilmu Pendidikan Islam, Jakarta : PT Bina Ilmu, 2004.

Rakhmat, Jalaludin, Islami Alternatif Ceramah-Ceramah Dikampus, Bandung: Mizan, 1993.

Shochib, Moh, Pola Asuh Orang Tua dalam Membantu Anak Mengembangkan Disiplin Diri, Jakarta: Rineka Cipta, 2010.

Suryabrata, Sumadi, , Psikologi Kepribadian, Jakarta: PT. Raja Grafindo Persada, 2000 .

Syah, Muhhibbin, Psikologi Pendidikan dengan Pendekatan Baru, Bandung: Remaja Rosdakarya, 2011.

Yusuf, Nursyamsiyah, Ilmu Pendidikan, Tulungagung : Pusat Penerbitan dan Publikasi, 2000.

Zakiah, Ilmu Pendidikan Islam, Jakarta : Bumi Aksara, 2008.

Zuhairini, Filsafat Pendidikan Islam, Jakarta: Bumi Aksara, 1991.

\section{Sumber Wawancara}

Abd. Rahman orang tua peserta didik SDN 325 Polewalie, Wawancara, di rumah.

Andi Intang, pendidik Kelas III, Wawancara, di SDN 325 Polewalie.

Darnawati, orang tua peserta didik SDN 325 Polewalie, Wawancara, di rumah. 
Hanafizah, kepala SDN 325 Polewalie, Wawancara, di ruangan kepala sekolah. Hasnawati, orang tua peserta didik SDN 325 Polewalie, Wawancara, di rumah. Herlina, orang tua peserta didik SDN 325 Polewalie, Wawancara, di rumah. Isia, orang tua peserta didik SDN 325 Polewalie, Wawancara, di rumah Jumerang, orang tua peserta didik SDN 325 Polewalie, Wawancara, di rumah Muh. Saleng, orang tua peserta didik SDN 325 Polewalie, Wawancara, di rumah. Muh. Yusuf, orang tua peserta didik, Wawancara, di kediaman Muh. Yusuf. Munawarah, orang tua peserta didik SDN 325 Polewalie, Wawancara, di rumah. Nelly, Pendidik Kelas VI SDN Polewalie, Wawancara, di Ruang Guru.

Nirwana, Pendidik Kelas IV SDN Polewalie, Wawancara, di Ruang Kelas IV Nunggu, orang tua peserta didik SDN 325 Polewalie, Wawancara, di rumah. Nurmiati, Pendidik Kelas I SDN 325 Polewalie, Wawancara, di Ruang Kelas I. Parmi, pendidik Kelas III, Wawancara, di SDN 325 Polewalie.

Rusli, orang tua peserta didik SDN 325 Polewalie, Wawancara, di rumah. Rusman, orang tua peserta didik SDN 325 Polewalie, Wawancara, di rumah Samsu, orang tua peserta didik SDN 325 Polewalie, Wawancara, di rumah. 